\title{
Know and grow: a qualitative evaluation of a parent skills training intervention
}

\author{
Gabrielle Goodier ${ }^{1}$, Julie McCormack ${ }^{2}$, Sarah Egan ${ }^{1}$, Hunna Watson², Gillian Todd ${ }^{3}$, Janet Treasure ${ }^{4,5}$, \\ Kimberley Hoiles ${ }^{2}$, Sue Lister ${ }^{2}$, Kaye James ${ }^{2}$
}

From 2014 ANZAED Conference: Driven Bodies Driven Brains

Fremantle, Australia. 22-23 August 2014

\section{Objective}

This qualitative study examined the experience of parents of children and adolescents with eating disorders after having participated in a skills-based training intervention.

\section{Method}

Participants were interviewed and transcripts were analysed using inductive thematic analysis.

\section{Results}

Parent responses were organised around key themes of (1) effectiveness and acceptability of the intervention; (2) interpersonal experience of the group process; and (3) feedback on intervention content. Overall, the program was seen by parents to be highly relevant with direct application to supporting their child in home and hospital environments.

\section{Discussion}

This study reports on preliminary evidence that skillsbased training is acceptable to parents and improves parent functioning including parent self-efficacy, and reduces psychological distress, anxiety, and burden. The study also demonstrated that the intervention can be delivered in a tertiary paediatric treatment setting and it may become cost-effective method for supporting parents and other carers. Future research is required on treatment efficacy and patient outcomes.

This abstract was presented in the Parental Roles in Prevention and Support stream of the 2014 ANZAED Conference.

\footnotetext{
* Correspondence: Julie.McCormack@health.wa.gov.au

${ }^{2}$ Specialised Child and Adolescent Mental Health Service, Princess Margaret Hospital for Children, Perth, Australia

Full list of author information is available at the end of the article
}

\section{Authors' details}

${ }^{1}$ School of Psychology and Speech Pathology, Curtin University, Perth, Australia. ${ }^{2}$ Specialised Child and Adolescent Mental Health Service, Princess Margaret Hospital for Children, Perth, Australia. ${ }^{3}$ South London and Maudsley NHS Trust, London, UK. ${ }^{4}$ Psychological Medicine Department, King's College London, London, UK. ${ }^{5}$ Institute of Psychiatry, London, UK.

Published: 24 November 2014

doi:10.1186/2050-2974-2-S1-036

Cite this article as: Goodier et al.: Know and grow: a qualitative evaluation of a parent skills training intervention. Journal of Eating Disorders 2014 2(Suppl 1):036.

\footnotetext{
Submit your next manuscript to BioMed Central and take full advantage of:

- Convenient online submission

- Thorough peer review

- No space constraints or color figure charges

- Immediate publication on acceptance

- Inclusion in PubMed, CAS, Scopus and Google Scholar

- Research which is freely available for redistribution

Submit your manuscript at www.biomedcentral.com/submit
} 